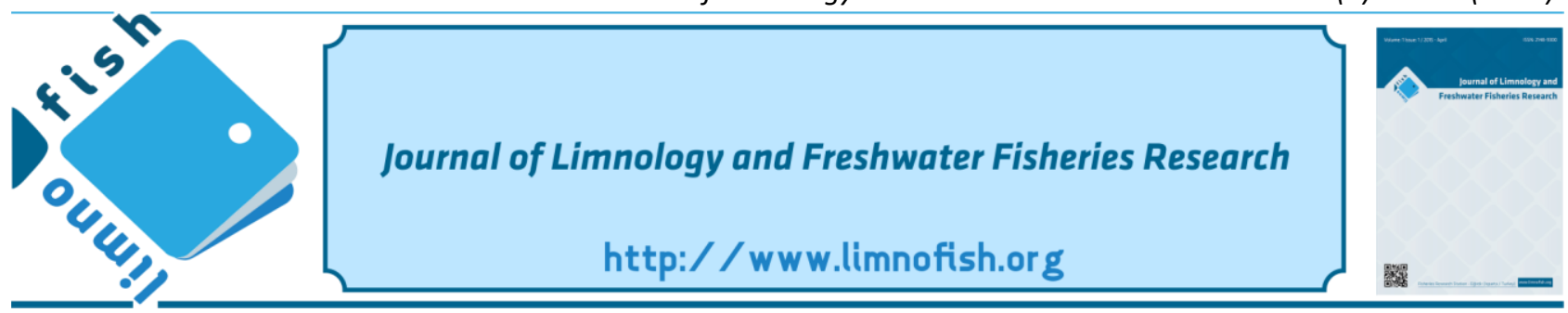

\title{
Socio-Economic and Cost Benefits of Catfish (Clarias gariepinus) Marketing in Obio-Akpor Local Government Area, Rivers State, Nigeria
}

\author{
Henry Eyina DIENYE ${ }^{1 *}$, Olaniyi Alaba OLOPADE ${ }^{1}$ (iD), Celestina Oluchi OBI ${ }^{1}$ \\ ${ }^{1}$ Department of Fisheries, Faculty of Agriculture, University of Port Harcourt Choba Nigeria, P.M.B.5323
}

\section{A B STR ACT}

This study aims to analyze the cost-benefit of catfish marketing in Obio- Akpor Local Government Area of Rivers State. A random sampling technique was adopted in sampling 60 catfish marketers in 5 catfish markets for the study. Data were collected with a structured questionnaire and were analyzed using descriptive statistics and regression models. Results showed that all respondents were female within the active working-age of 31-50 years. Married catfish marketers were $33.3 \%$, and $80 \%$ had formal education. The profitability of catfish marketing indicated a total mean total variable cost (TVC), $\$ 68,119.17$, the total mean total fixed cost (TFC), $₹ 2,131.75$, the total mean total cost of production (TCP), $\$ 70,250.92$, mean total revenue (TR) recorded $\$ 181,000.00$, and mean net income (NI), 137,572.08. mean gross margin value (GM) recorded $\$ 139,635.83$, while the profitability index (PI) 1.31. The variables which influenced the profitability of catfish marketing were age, educational level, number of the sales point, and capital. The high cost of transportation, unstable price, and poor access road were the major constraints to catfish marketing. The source of startup capital was personal savings It is recommended that catfish marketers form a cooperative society to enhance their access to finance and regulate pricing with relevant variables that significantly influenced net income and should be considered in policy issues.

\section{ARTICLE INFO}

RESEARCH ARTICLE

Received : : 13.07.2020

Revised : :26.09.2020

Accepted : :08.10.2020

Published : 29.04.2021

DOI:10.17216/LimnoFish.768909

* CORRESPONDING AUTHOR

henry.dienye@uniport.edu.ng

Phone : +2348036809439

Keywords: Profitability, catfish marketers, constraint, Obio-Akpor

How to Cite

Dienye HE, Olopade OA, Obi CO. 2021. Socio-Economic and Cost Benefits of Catfish (Clarias gariepinus) Marketing in Obio-Akpor Local Government Area, Rivers State, Nigeria. LimnoFish. 7(1): 40-48. doi: 10.17216/LimnoFish.768909

\section{Introduction}

Fish farming is a branch of aquaculture that deals with the culture of fish, which can be pond (concretes or earthen), wood, fiberglass, and plastic enclosure in a managed environment Nwokoye et al. (2007). For many developing countries, catfish is one of Africa's most commercially important freshwater fish. Its trade gives local producers significant employment and contributes to curbing food insecurity in the population (FAO 2006). Ebewore (2013) opined that most Nigerians are unable to meet the protein requirement because of their poverty level. The protein needed for growth, particularly in children, was inadequate because the animal protein was expensive. Protein from fish sources within reach is the only cheaper source of protein to bridge the gap of protein deficiency. Despite Nigeria's popularity, fish farming can be better represented as a child in comparison with the huge market potential for production and marketing (Nwiro 2012). Fish supply is from four major sources viz., artisanal fisheries, industrial trawlers, aquaculture, and imported frozen fish (Akinrotimi et al. 2011).

According to Adegeye and Dittoh (1985), marketing is a process that involves identifying the desires and needs of consumers and providing acceptable food and services which meet the needs and wishes of consumers and business managers to the benefit. The transport of goods to the customer requires the production of various types of services, including manufacturing, storage, preservation, distribution, wholesales, and retailing, using economic activities. The process of handling and marketing catfish is very delicate if quality and nutritional value are to be maintained due to its short shelf life. Fish culture has been noted by Eyo et al. 
(2003) as the surest way of bridging the widening gap between the demand and supply of food fish in this country. This has fostered increased interest in the production of fish, especially catfish. Consequently, live-catfish marketing experienced fast growth to match the increasing supplies from the production sector. Such growth has created many opportunities for jobs at different marketing levels, thereby improving participants' income and well-being. (Ugwumba and Chukwuji 2010). The increasing demand gap can also be attributed to an inefficient marketing network, due to marketing issues such as lack of knowledge in the sector, weak business structures, high freight costs and lack of resources, inefficient warehousing facilities, restricted markets, and several intermediaries (Ugwumba 2010).

Marketing is a method of bringing the forces of demand and supply together regardless of the location of the market (Adekanye 1988). An effective marketing mechanism means that the supply of products across the year, regardless of the seasonality, no variance in prices, due to high marketing costs including storage. It is against this background that the study was carried out to determine the socio-economic and cost-benefit of catfish marketing in five major markets in ObioAkpor LGA of Rivers State.

\section{Materials and Methods \\ Study Area}

The study was carried out in Obio- Akpor Local Government Area, in the metropolis of Port Harcourt, one of the major centers of economic activities in Rivers State, Nigeria. It is located between latitude $04^{\circ} 49^{\prime} 06.50^{\prime \prime} \mathrm{N}$ and longitude $04^{\circ} 60^{\prime} 08.00^{\prime \prime} \mathrm{E}$ (Figure 1). The local government covers $260 \mathrm{~km}$ and at the 2006 census held a population of $464,789.00$ The original indigenous occupants of the area are the Ikwerre people.

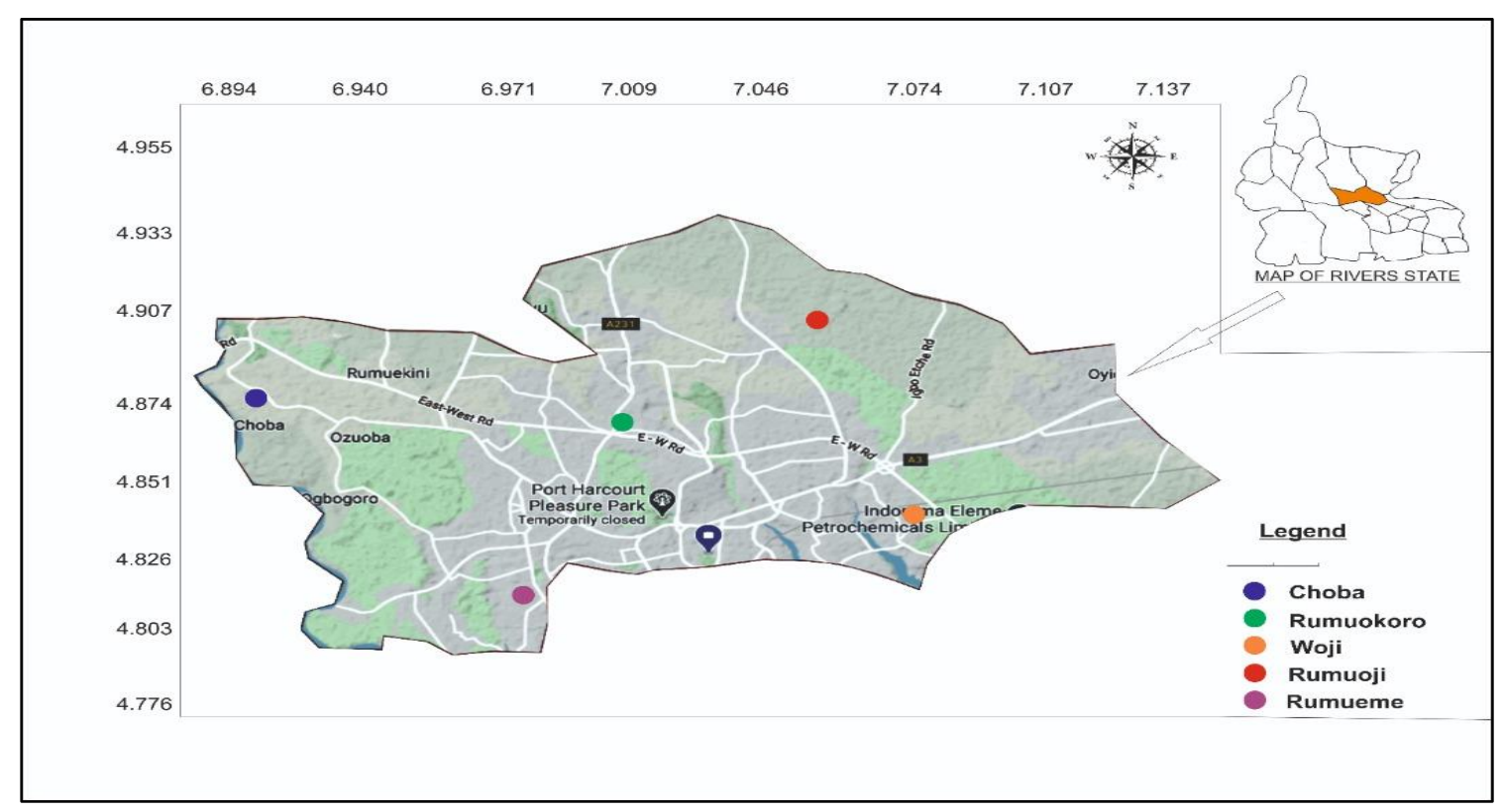

Figure 1. Map of five major fish markets in Obio-Akpor LGA.

\section{Data Collection}

The five major catfish markets in the Obio-Akpor Local Government Area were studied. Twelve catfish sellers were randomly selected from each market to make a total of sixty respondents. Data were collected from catfish marketers using a structured questionnaire. The questionnaire administered elicited information on the socioeconomic characteristics of respondents, sources of finance, constraints affecting sales, catfish price marketing characteristics of the fresh fish marketers, costs and returns and problems encountered by fresh fish marketers, etc. the response of these farmers formed the primary data used.

\section{Data Analyses}

Descriptive statistics analysis such as percentage, frequencies were used to describe the socioeconomic characteristics of the respondents, marketing channel, and constraints to fresh fish marketing in the study area using Statistical Package for Social Science (SPSS) 16.0 windows SPSS software package.

\section{Cost and Returns Analysis}

This analysis was used to determine the profitability of catfish marketing. The profitability 
analyses employed were fixed cost $(F C)$, variable cost $(V C)$, total cost $(T C)$, total revenue $(T R)$, gross margin $(G M)$, and profit (Adebayo and Daramola 2013).

\section{Cost.}

Total Cost $=$ Total Variable Cost + Total Fixed

Total Revenue $=P X Q(P=$ Price and $Q=$ Total output ( $k g)$ )

$$
\begin{aligned}
& G M=T R-T V C \text { where } \\
& G M=\text { Gross margin } \\
& T R=\text { Total revenue } \\
& T V C=\text { total variable cost } \\
& \text { Profit }=\text { GM-TFC where: } \\
& G M=\text { Gross margin } \\
& T F C=\text { Total fixed cost }
\end{aligned}
$$

\section{Regression Analysis}

The regression analysis was carried out to examine the factors affecting the market profit of fresh fish sellers. The dependent variable is profit obtained by sellers in the market, while the exogenous variables are the factors affecting the level of profit, such as marketing experience, level of education, the quantity of fish purchased, and operational cost (Adesina and Djato 1996; Squires et al. 1998). Four functional forms were fitted, these were linear, semi-log, double log, and exponential. The model with the best fit was then chosen as the lead equation following Gujarati (1995), and Olayemi (1998).

\section{Results}

Table 1 showed the socio-economic characteristics of fish sellers, all were females. Half of the respondents were within the age range of 4150 years, $38.3 \%$ within $31-40$ years while $1.7 \%$ were within the 20-30 years old age group. Catfish sellers $(33.3 \%)$ were married, $31.7 \%$ separated, $11.7 \%$ single, $18.3 \%$ widows while only $5.0 \%$ of the respondents were divorced. All the fish sellers $(100 \%)$ were Christian. The study also revealed that $30 \%$ had secondary education, $16.7 \%$ had primary education while only $3.3 \%$ had non-formal

\begin{tabular}{|c|c|c|}
\hline Item & Frequency & Percentage \\
\hline \multicolumn{3}{|l|}{ Sex: } \\
\hline Males & 0 & 0 \\
\hline Female & 60 & 100.0 \\
\hline Total & 60 & 100.0 \\
\hline \multicolumn{3}{|l|}{ Age (Years) } \\
\hline $20-30$ & 1 & 1.7 \\
\hline $31-40$ & 23 & 38.3 \\
\hline $41-50$ & 30 & 50.0 \\
\hline $51-60$ & 6 & 10.0 \\
\hline \multicolumn{3}{|l|}{ Marital status } \\
\hline Single & 7 & 11.7 \\
\hline Married & 20 & 33.3 \\
\hline Separated & 19 & 31.7 \\
\hline Divorced & 3 & 5.0 \\
\hline Widow & 11 & 18.3 \\
\hline Total & 60 & 100.0 \\
\hline \multicolumn{3}{|l|}{ Religion } \\
\hline Christian & 60 & 100.0 \\
\hline Total & 60 & 100.0 \\
\hline \multicolumn{3}{|l|}{ Educational Level } \\
\hline Non-formal education & 2 & 3.3 \\
\hline Primary school education & 10 & 16.7 \\
\hline Secondary school education & 18 & 30.0 \\
\hline Post-secondary school education & 30 & 50.0 \\
\hline Total & 60 & 100.0 \\
\hline \multicolumn{3}{|l|}{ Main Occupation } \\
\hline Full-Time Fish Seller & 54 & 90.0 \\
\hline Part-Time Fish Seller & 6 & 10.0 \\
\hline Total & 60 & 100.0 \\
\hline Motivating Factor for Employment & 60 & 100.0 \\
\hline Total & 60 & 100.0 \\
\hline
\end{tabular}
education. Furthermore, the table showed that $90 \%$ of the respondents were full-time fish sellers and only $10 \%$ combined other economic activities with the selling of fresh catfish. Employment was the only motivation factor reported by the respondents.

Table 1. Socio-economic characteristics of fish sellers. 
The transportation systems and challenges of catfish as shown in table 2 below, revealed that all the respondents use public transportation as a means of transporting the fish (100\%) and most of them experienced mortality $(91.7 \%)$. The mortality rate as a result of transportation challenges ranged from, 510pieces $(51.7 \%), 1-5$ pieces $(35.0 \%)$ 11-20 pieces $(13.3 \%)$ respectively. Daily mortality recorded were as follows 1 piece (15.0\%), 2 pieces $(45.0 \%)$ while 4 5 pieces $(18.3 \%)$ recorded the highest mortality.

Table 2. Challenges of transporting Fresh Catfish by fish sellers.

\begin{tabular}{lcc}
\hline Item & Frequency & Percentage \\
\hline Transportation System & \multicolumn{2}{c}{} \\
Public transportation & 60 & 100.0 \\
Total & $\mathbf{6 0}$ & $\mathbf{1 0 0 . 0}$ \\
\hline Transport Mortality & & \\
Yes & 55 & 91.7 \\
No & 5 & 8.3 \\
Total & $\mathbf{6 0}$ & $\mathbf{1 0 0 . 0}$ \\
\hline Mortality Rate & & \\
$1-5$ & 21 & 35.0 \\
$5-10$ & 31 & 51.7 \\
$11-20$ & 8 & 13.3 \\
Total & $\mathbf{6 0}$ & $\mathbf{1 0 0 . 0}$ \\
\hline Daily Mortality & & \\
1 & 9 & 15.0 \\
2 & 27 & 45.0 \\
3 & 13 & 21.7 \\
$4-5$ & 11 & 18.3 \\
Total & $\mathbf{6 0}$ & $\mathbf{1 0 0 . 0}$ \\
\hline So: Fidd
\end{tabular}

Source: Field survey 2019

Table 3 below showed the various methods employed by catfish sellers in keeping fish alive. Forty-five percent employed constant changing of water as a means of preservation while $20 \%$ made use of sack to cover their catfish. Other unconventional methods were the use of slaughtered fish fat to feed the fish $(11.7 \%)$, pouring of oil on the water $(3.3 \%)$, use of leftover bread to feed $(8.3 \%)$, adding lady's finger (Okra) to water $(8.3 \%)$ and feeding with indomie waste noodles $(3.3 \%)$. None of catfish sellers made use of anti-stress on their fish.

Table 3. Conventional and unconventional methods used to keep the Fresh fish alive.

\begin{tabular}{lcc}
\hline Item & Frequency & Percentage \\
\hline Covering with sacks & 12 & 20.0 \\
Feed with fats of slaughtered fish & 7 & 11.7 \\
Use of palm oil & 2 & 3.3 \\
Use of bread to feed & 5 & 8.3 \\
Adding ladies' fingers to water (Okra) & 5 & 8.3 \\
Feeding with noodles & 2 & 3.3 \\
Changing of water & 27 & 45.0 \\
Total & $\mathbf{6 0}$ & $\mathbf{1 0 0 . 0}$ \\
\hline Anti-stress & & 100.0 \\
None & 60 & $\mathbf{1 0 0 . 0}$ \\
Total & $\mathbf{6 0}$ & \\
\hline
\end{tabular}

Source: Field survey 2019

The costs and returns associated with marketing catfish in the study area were presented in Table 4. The total mean variable cost (TVC) was $\$ 68,119.17$, the total mean fixed cost (TFC) was $2,131.75$, the total mean cost of production (TCP) was $\$ 70,250.92$, mean total revenue (TR) recorded was $\$ 181,000.00$, and mean net income (NI) was $\$ 137,572.08$, mean gross margin value (GM) recorded was $\$ 139,635.83$, while the profitability index (PI) was 1.31 .
Figure 2 below showed the factors militating against fresh catfish marketing by respondents. The survey revealed that transportation cost $(41.7 \%)$, unstable price of fish $(21.7 \%)$, lack of capital $(6.7 \%)$, hike in the price of fish $(5 \%)$, inadequate holding/storage facilities $(3.3 \%)$ and bad roads to access farms $(21.7 \%)$ were identified by the respondents as limitations and challenges. 
Table 4. Monthly Costs and Returns Analysis of Fresh catfish marketing in Obio-Akpor LGA.

\begin{tabular}{l|c|c|c|c|c}
\hline Variable & $\mathbf{N}$ & Minimum (N) & Maximum (A) & Mean (N) & Std. Deviation (A) \\
\hline Labor cost & 60 & 1000.00 & 1550.00 & 1009.17 & 71.00 \\
Transportation cost & 60 & 500.00 & 1550.00 & 1165.00 & 510.26 \\
Levy and due & 60 & 100.00 & 150.00 & 111.67 & 21.33 \\
Purchase of catfish & 60 & 50000.00 & 975000.00 & 65833.33 & 119405.89 \\
Total Variable Cost & 60 & 51600.00 & 977650.00 & 68119.17 & 119454.32 \\
\hline Knife & 60 & 100.00 & 200.00 & 119.17 & 29.24 \\
Bowl & 60 & 200.00 & 450.00 & 294.17 & 83.91 \\
Basket & 60 & 100.00 & 120.00 & 115.17 & 8.53 \\
Sack & 60 & 70.00 & 90.00 & 72.416 & 3.50 \\
Scale & 60 & 1200.00 & 2500.00 & 1530.83 & 566.07 \\
Total Fixed Cost & 60 & 1740.00 & 3150.00 & 2131.75 & 563.99 \\
\hline Total Cost (TVC+ TFC) & 60 & 53345.00 & 979690.00 & 70250.92 & 119440.67 \\
Total Revenue & 60 & 150000.00 & 220000.00 & 181000.00 & 32230.63 \\
Gross Margin (TR-VC) & 60 & 72850.00 & 802650.00 & 139635.83 & 93091.13 \\
Net Income & 60 & 71090.00 & 804490.00 & 137572.08 & 93544.17 \\
Profitability Index & 60 & 1.47 & 1.69 & 1.31 & 1.07689 \\
\hline Source: Fidd survey 2019 & & & & &
\end{tabular}

Source: Field survey 2019

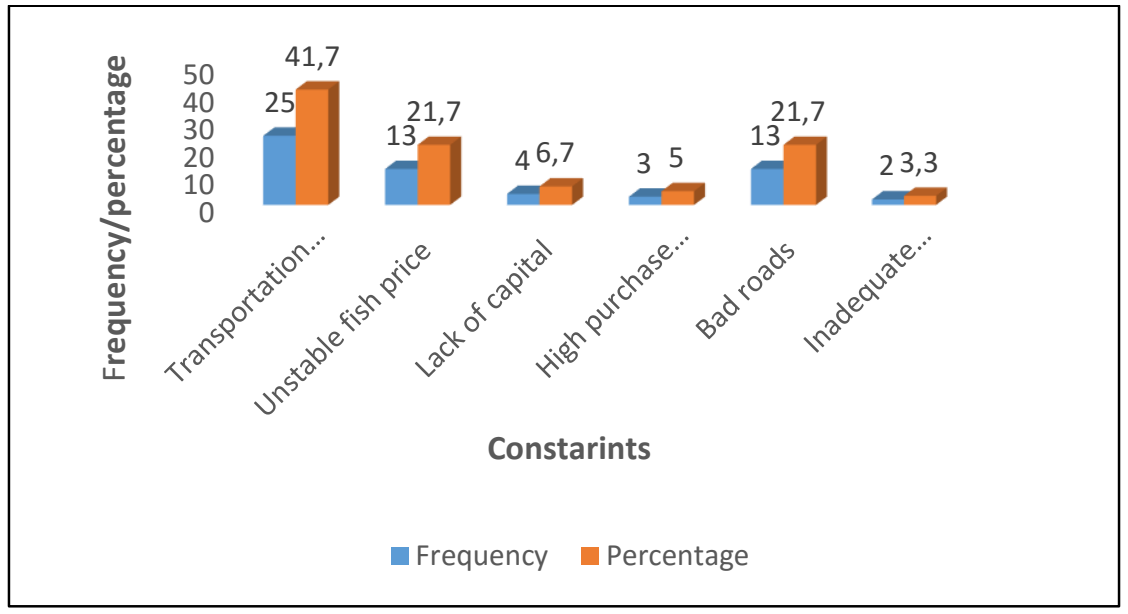

Figure 2. Major Constraints to Catfish Marketing System in the Study Area

Figure 3 below revealed the source of startup capital for respondent's personal savings recorded the highest with $(78.3 \%)$, while $(18.3 \%)$ of the respondents got finance from daily contribution/private lenders and only (3.3\%) obtained loan from the bank.

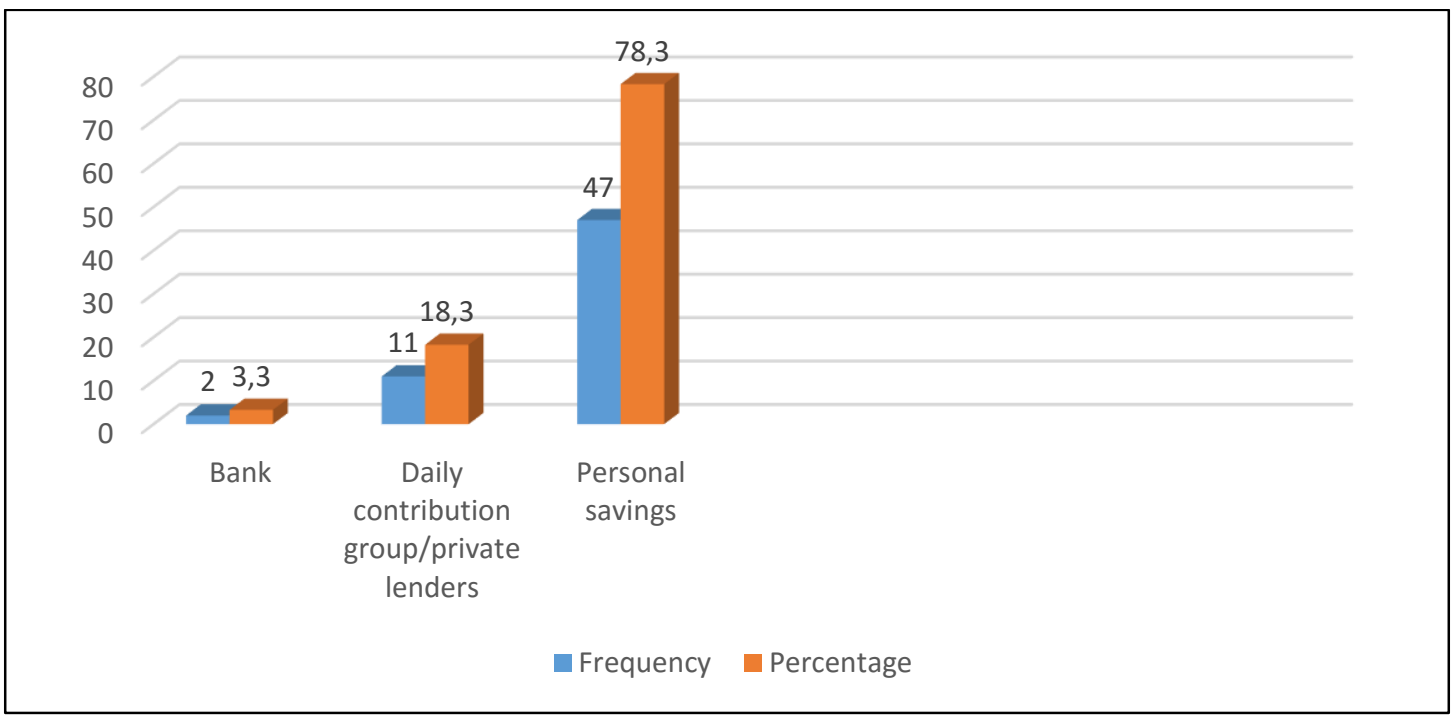

Figure 3. Source of startup capital 
The result of the ordinary least square (OLS) regression analysis carried out to examine the determinants of profitability of catfish marketing in the study area as shown in Table 5, revealed that age, educational level, number of the sales point, and capital for catfish marketing showed a positive coefficient with the level of profit from catfish marketing and significant ( $\mathrm{P} \geq 0.01)$. The coefficients are in line with the prior expectation. The $\mathrm{R}^{2}$ value of 0.815 showed that 81.5 percent of the variation in the level of profit from fresh fish marketing was jointly explained by the independent variables specified in the regression model.

Table 5. Determinants of profitability of fresh Catfish marketing in Obio-Akpor LGA.

\begin{tabular}{ccc}
\hline Variables & Coefficients & t-value \\
\hline (Constant) & -0.214 & -1.567 \\
Age & $0.020^{* *}$ & 0.061 \\
Educational level & $0.044 * * *$ & 5.127 \\
Sales point & $0.336^{* * *}$ & 2.587 \\
Labor & $-0.007 * *$ & -2.033 \\
Catfish sale per day & 0.065 & 0.167 \\
Capital & $0.413 * * *$ & 2.557 \\
f-value & & 711 \\
R Square & & 0.835 \\
Adjusted R Square & & 0.815 \\
\hline
\end{tabular}

***Significant $((\mathrm{P} \geq 0.01)$; **Significant $(((\mathrm{P} \geq 0.05)$

Source: Field survey (2019).

\section{Discussion}

Women are generally involved in marketing fresh catfish in Nigeria, as women are well known to boost the efficiency and competitiveness of any venture in which they are involved, due to their accommodating and diligent approach to activities (Raney et al. 2011; Doss 2018). The result of this study showed that all fresh catfish sellers were female which is in contrast with the findings of Ayanboye et al. (2015) who reported $85 \%$ female and $15 \%$ male in Ibarapa zone of Oyo, State and Njoku and Offor (2016) who stated that $65 \%$ of catfish sellers were males and $35 \%$ female in Aba South LGA of Abia State.

Youth appear to be enthusiastic, adapt, and embrace emerging technology more easily and therefore more efficient than those who are perhaps older. Age is a key factor in the productivity and profitability performance of catfish sellers (Ngeywo et al. 2015). The result of this study indicates that most of the marketers were in their middle age class, which is an important factor in catfish marketing activities. This is in agreement with the findings of Ebewore (2013), who reported that people involved in economic activities (Catfish marketers) are in their economic active age and were able to actively participate in the business.

Studies have shown that healthy marriages increase business profitability by about twenty percent (Ahituv and Lerman 2005) and this suggests that marriage will improve employment, efficiency, and profitability. Marriages tend to have more household responsibilities than individuals and thus they meet family life demands. Also, the ability of the household to supply the needed labor in the catfish business depends to a large extent on the marital status (Agbugba et al. 2014). The findings of Ayanboye et al. (2015) corroborate the result of this study that married people dominate the cat-fish marketing business and are also an indication of the productive potential of the catfish business to support household livelihood. Stability provides a favorable atmosphere, essential for efficient management of resources, good citizen training, and personal integrity growth. Nwaru (2004) which is indicated in the findings of this study.

The literacy rate which can be measured through formal education is considered a crucial element for improving human capital, the less expensive training of the literate can be done and the socio-economic status is generally higher. Lareau (2003) noted that higher levels of education were associated with better economic and psychological outcomes. The findings of this study revealed that the majority of the catfish farmers were fairly educated with 50\% postsecondary education. An additional year of education has been shown to increase the probability of productivity of an individual by $4.8 \%$. This agrees with the findings of Nkamleu and Adesina (2000) and Adeogun et al. (2008) who found that level of education had a positive and significant influence on catfish marketers economically.

According to FAO (2017b), startup capital can be difficult for aquaculture marketing business. The establishment of this value chain business can take account of private capital from partners, whether active or silent. The ability to acquire sufficient capital is a key factor in which startup capital is a key part of the study for catfish marketers, primarily from 
personal savings. The catfish sellers used conventional and unconventional methods to keep the fish alive. The final consistency of the product would be influenced by product handling during transport and marketing.

The variables that were significantly included, age, educational level, the number of the sales point, and capital. Salespoint, capital, and educational level were significant $(\mathrm{P} \geq 0.01)$ respectively, and were positively related to the profit from fresh catfish marketing. The higher the capital the catfish marketer was able to invest into the business, the higher the profit accrue to them, which is in line with findings of Sikiru et al. (2009) who identified inadequate finance as a serious problem in catfish production and marketing.

The $\mathrm{R}^{2}$ value of 0.835 was obtained in this study, which implies that $83.5 \%$ of the total variation in the dependent variable was accounted for by variation in the independent variables. This indicates the goodness of fit for the model and the relevance of the variables fitted into the model. The educational level was significant $(\mathrm{P} \geq 0.01)$ with a positive coefficient to profit from fresh catfish marketing. This implies that, with an increase in the years of schooling by fresh fish marketers, more profit will be accrued to them. This is also in line with the educational level because as one's educational level increases, it enables one to access and conceptualize improved marketing techniques and other related issues capable of enhancing one's performance (Apata et al. 2010). The proportion of labor involved in catfish marketing was negatively significant $(\mathrm{P} \geq 0.05)$ This implies that as labor increases, net income reduces due to the influenced level of profit that accrues to fresh catfish marketers in the study area. This might be as a result of labor collecting wages from the fresh fish marketers which ought to have been added to the total revenue thereby leading to more profit. The sales point was significant $(\mathrm{P} \geq 0.01)$ and positively related to the net income of the marketers. This denotes that the number of sales points or the number of catfish sold significantly affects the level of net income of the marketers. An increase in the quantity of fish $(\mathrm{kg})$ sold in turn leads to an increase in net income of the catfish marketers. This implies that as the number of sales point increase, net income also increases. This result agrees with the findings of Offor and NseNelson (2015) who opined that marketing experience/number of sales points has a significant influence on net income and marketing efficiency.

Major constraints recorded in this study agreed with the findings of (Davis and Schreck 1997). This result also corroborates the findings of Akankali and Jamabo (2011), who reported that unavailability of adequate transport and capital were hindrances to effective distribution of goods from one point to another. Handling and transport are inherently stressful and excessive crowding of fish before sales can also be stressful, with potential decreases in oxygen levels and water quality increased chances of abrasion, and rapid changes in light intensity (HSA 2005). The net income was positive at $\$ 137,572.08$, this indicates that the business is profitable and this corroborates the finding of Olasunkanmi and Yusuf (2014). The gross margin in this study was 139,635.83, which is in line with the findings of Ugwumba and Chukwuji (2010) and Emokaroet al. (2010).

The study examined the socio-economic and cost benefits of marketing fresh catfish in Obio-Akpor Local Government Area of Rivers State. The most significant variables that influenced the profitability of catfish marketing were age, educational level, the number of sales points, and capital, while the major limitations against catfish marketing were the high cost of transportation, unstable price, and poor access road. The startup capital was mostly personal savings among others. Catfish marketers should form fish marketing co-operative, as this would help regulate unstable fluctuation in prices, increase their access to credit from the financial institution, and hence help ease the problem of inadequate capital. There should be the availability of infrastructure such as good feeder roads that link the rural areas to major cities, this would reduce the cost of transportation thereby reducing the total cost of production and increasing net income.

\section{References}

Adebayo OO, Daramola OA. 2013. Economic analysis of catfish (Clarias gariepinus) production in Ibadan metropolis. Discourse Journal of Agriculture and Food Sciences. 1(7):128-134.

Adegeye AJ, Dittoh JS. 1985. Essentials of Agricultural Economics. Ibadan, Nigeria: Impact Publishers $251 \mathrm{p}$.

Adekanye TO. 1988. Readings in agricultural marketing. Ibadan: Longman Nigeria Limited $251 \mathrm{p}$.

Adeogun OA, Ajana AM, Ayinla OA, Yarhere MT, Adeogun MO. 2008. Application of logit model in adoption decision: a study of hybrid clarias in Lagos State, Nigeria. American-Eurasian Journal of Agriculture and Environmental Sciences. 4(4):468472.

Adesina AA, Djato KK. 1996. Farm size, relative efficiency and agrarian policy in Côte d'Ivoire: profit function analysis of rice farms. Agr Econ. 14(2):93102. doi: 10.1016/0169-5150(96)01181-4

Agbugba IK, Ihemezie EJ, Ahmed EA. 2014. Informal sources of financing climate change adaptation amongst crop farmers in Nigeria. International Journal of Agricultural Science, Research and Technology (IJASRT) in EESs. 4(1):7-13. 
Ahituv A, Lerman RI. 2005. How Do Marital Status, Wage Rates, and Work Commitment Interact? Demography. 44(3):623-647.

Akankali JA, Jamabo NA. 2011. A review of some factor militating against sustainable artisanal fisheries development in Niger Delta, Nigeria. Asian Journal of Agricultural Sciences. 3(5):369-377.

Akinrotimi OA, Abu OMG, Aranyo AA. 2011. Environmentally Friendly Aquaculture Key Sustainable Fish Farming Development in Nigeria. Continental Journal Fisheries and Aquatic Science. 5(2):17-31.

Apata TG, Ogunyinka AI, Sanusi RA, Ogunwande S. 2010. Effect of Global Climate Change on Nigeria Agriculture: An Empirical Analysis. Paper presented at: the 84th Annual Conference of the Agricultural Economics Society; Edinburgh, Scotland.

Ayanboye AO, Oluwafemi ZO, Rafiu RA. 2015. Fresh fish (Clarias gariepinus) marketing system in major towns of Ibarapa zone, Oyo State, Nigeria. International Journal of Applied Agricultural and Apicultural Research. 11(1-2):162-171

Davis LE, Schreck CB. 1997. The energetic response to handling stress in juvenile coho salmon. T Am Fish Soc.126(2):248-258. doi: 10.1577/1548-8659(1997)126

Doss CR. 2018. Women and agricultural productivity: Reframing the Issues. Dev Policy Rev. 36(1):35-50. doi: 10.1111/dpr.12243

Ebewore SO. 2013. Assessment of the Marketing of Frozen Fish (Iced Fish) in Edo State, Nigeria. Asian Journal of Business Management. 5(4):353-357.

Emokaro CO, Ekunwe PA, Achille A. 2010. Profitability and viability of catfish farming in Kogi State, Nigeria. Research Journal of Agriculture and Biological Sciences. 6(3):215-219.

Eyo AA, Ayanda JO, Falayi BA, Adelowo EO. 2003. Economic Prospects of Investment in Integrated Fish Cum Livestock Farming. Paper presented at: 18th Annual Conference of the Fisheries Society of Nigeria (FISON); Owerri, Nigeria.

FAO 2006. Food and Agriculture Organization of the United Nations. FishStat Plus - Universal software for fishery statistical time series - Fisheries Department, Fishery Information, Data and Statistics Unit Version 2.30; [cited 2020 Feb 01]. Available from http://www.fao.org/fishery/statistics/software/fishstat /en

FAO 2017b. Food and Agriculture Organization of the United Nations. The State of food and agriculture: leveraging food systems for inclusive rural transformation; [cited 2020 Jan 10]. Available from www.fao.org/3/a-i7658e.pdf

Gujarati DN. 1995. Basic Econometrics. New York: McGraw- Hill International Edition 838 p.

HSA 2005. Human Slaughter Association. Humane Harvesting of Salmon and Trout. Wheathampstead, UK; Humane Slaughter Association 19 p.

Lareau A. 2003. Unequal Childhoods: Race, Class, and Family Life. Berkeley: University of California Press $343 \mathrm{p}$.
Ngeywo J, Basweti E, Shitandi A. 2015. Influence of Gender, Age, Marital Status and Farm Size on Coffee Production: A Case of Kisii County, Kenya. Asian Journal of Agricultural Extension, Economics and Sociology. 5(3):117-125.

Njoku ME, Offor EI. 2016. Cost and Returns Analysis of Catfish Marketing in Aba South Local Government Area of Abia State, Nigeria. Journal of Tropical Agriculture, Food, Environment and Extension. 15(2):9-14. doi: $10.4314 /$ as.v15i2.2

Nkamleu GB, Adesina AA. 2000. Determinants of chemical input use in peri-urban lowland systems: bivariate probit analysis in Cameroon. Agr Syst. 63(2):111-121. doi: 10.1016/S0308-521X(99)00074-8

Nwaru JC. 2004. Rural Credit Market and Arable Crop Production in Imo State of Nigeria. [PhD Thesis]. Michael Okpara University of Agriculture Umudike, Nigeria. 302p.

Nwiro E. 2012. Fish farming a lucrative business; [cited 2020 Jan 20]. Available from http://www.thisdaylive.com/articles/fish-farming-alucrative-business/119253/

Nwokoye CO, Nwuba LA, Eyo JE. 2007. Induced propagation of African clarid catfish, Heterobranchus biodorsalis (Geoffrey Saint Hillarie, 1809) using synthetic and homoplastic hormones. Afr J Biotechnol. 6(23):2687-2693.

Offor EI, Nse-Nelson FA. 2015. Marketing Efficiency of Poultry Egg in Umuahia South Local Government Area of Abia State, Nigeria. International Journal of Applied Research and Technology. 4(6):3-7.

Olasunkanmi NO, Yusuf O. 2014. Resource use efficiency in small scale catfish farming in Osun State, Nigeria. Sky Journal of Agricultural Research. 3(1):37-45.

Olayemi JK. 1998. Elements of Applied Econometrics. Ibadan, Nigeria: A Publication of the Department of Agricultural Economics, University of Ibadan 250 p.

Raney T, Gustavo A, Croppenstedt A, Gerosa S, Lowder S, Matuschke I, Skoet J, Doss C. 2011. The role of women in agriculture. Rome, Italy: FAO. Report No: $11-02$.

Sikiru BO, Omobolanle NM, Ayorinde BJO, Adegoke OO. 2009. Improving Clarias productivity towards achieving food security in Ijebu-Ode, Ogun State, Nigeria: A socioeconomic analysis. Advances in Biological Research. 3(1-2):24-28.

Squires D, Grafton RQ, Alam MF, Ishak HO. 1998. Where the land meets the sea: Integrated sustainable fisheries development and artisanal fishing. San Diego, USA: University of California. Report No.: 9826

Ugwumba COA. 2010. The Agribusiness of Catfish Marketing for Poverty Alleviation and Women Empowerment in Anambra State, Nigeria. In: Okoh RN, editor. Engendering Policy for Attainment of Millenium Development Goals. Asaba, Nigeria: Proceedings of 1st Annual National Conference of Centre for Human Resource and Gender Services. p. 89-98. 
Ugwumba COA, Chukwuji CO. 2010. The economics of catfish production in Anambra State, Nigeria: a profit function approach. Journal of Agriculture and Social Sciences. 6(4):105-109. 